\title{
The Effectiveness of U-Shape Seating Arrangement Strategy for Discussion in Speaking Class
}

\author{
Rohdearni Wati Sipayung ${ }^{1}$, Benarita ${ }^{2}$ \\ ${ }^{1,2}$ Faculty of Teacher Training and Education, Universitas Simalungun, Indonesia \\ mailto:dearsipayunk@gmail.com,mailto:benaritapurba@yahoo.com
}

\section{Abstract}

This resaerch is focused on the effectiveness of $U$-Shape seating arrangement strategy for discussion in speaking class at teh first grade students of SLTP Negeri 2 Pematang Raya. The Problem of this research are: 1) How does the teacher implement $U$-Shape seating arrangement for discussion in speaking class of the first grade students at SLTP Negeri 2 Pematang Raya? ; 2) Is U-Shape seating arrangement effective for discussion in speaking class of the first grade students at SLTP Negeri 2 Pematang Raya? : 3) What are the students' responses toward $U$-Shape seating arrangement for discussion? The objective of this research are: 1) To describe implementation of $U$ Shape seating arrangement for discussion in speaking class of the first grade students at SLTP Negeri 2 Pematang Raya; 2) To analyze the effectiveness of $U$-Shape seating arrangement for discussion in speaking class of the first grade students at SLTP Negeri 2 Pematang Raya; 3) To know the students' responses toward U-Shape seating arrangement for discussion. From the data anaysis it can be concluded that: 1) The teacher uses her strategy to implement $U$-shape seating arrangement for discussion in speaking class of the first grade students at SLTP Negeri 2 Pematang Raya. U-shape seating arrangement is effective for discussion due to some proofs. First, $U$-shape seating arrangement helps the teacher leading the discussion well. The teacher can clearly give instruction to the students, easily monitor the students, and easily interact with the students during discussion in $U$-shape seating arrangement on the first day and second day observation; 2) The students show good responses toward U-shape seating arrangement for discussion. $55.56 \%$ of number of the students state that they like implementing $U$-shape seating arrangement for discussion, and $22.22 \%$ of number of the student's state that they like implementing $U$-shape seating arrangement for discussion very much. Besides, $51.85 \%$ of the students state that they feel comfortable with $U$ shape seating arrangement for discussion, and $33.33 \%$ of them state that they feel much comfortable.
Keywords

U-Shape; seating arrangement strategy; speaking

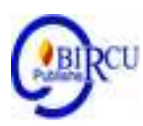

\section{Introduction}

English is an international language that is spoken and learned by people in almost entire the world. Nowadays, English becomes an important thing in many areas of human life. English has main function as a means of communication, because almost all of people from countries around the world speak English as world medium language. English has many 
skills such as listening, speaking, reading and writing. All of these skills are important for learners, and each skill has its own function. Among those four skills, speaking seems intuitively to be the most important skill to master due to some reasons.

Seating arrangements allow the students to consider class in a different perspective, work with other people, and check out information with a different angle.

Furthermore, according to Woolfolk, designing the physical arrangement of the class furniture, materials, and learning tools can affect learning environments. (Anita Woolfolk, 2007: 452).

In conclusion, an appropriate seating arrangement can support teaching and learning process. One kind of seating arrangements is U-Shape seating arrangement that is analyzed by the researcher. In researcher's opinion, U-Shape arrangement may be able to help discussion class to be more effective, because all of desks touch each other facing the front of the room in the U-shape. Here, the students are expected to discuss and express their own opinion actively and freely, while teachers are monitoring the process. Therefore, students can more actively discuss the material in U-Shape seating arrangement. John W. Santrock (2006:246), in his book entitled Educational Psychology, stated that "U-Shape seating arrangement is especially effective when you (teacher) want students to talk each other, or to converse with you (teacher)".

It's also parallel what Syaiful Bahri Djamarah (2005:175) said in his book. He stated that "it's better to implement U-Shape seating arrangement for discussion in teaching and learning process". According to the explanations above, the researcher can conclude that Ushape seating arrangement is appropriate to use for discussion. Also, U-shape seating arrangement may be able to elicit wider participation of students, so the discussion can run effectively. Due to those reasons, the researcher does the research about the effectiveness of U-Shape seating arrangement for discussion in speaking class at the first grade students of SLTP Negeri 2 Pematang Raya. This school has English teachers who are competent in their discipline. There, classrooms also have wide spaces so it is easy to rearrange seats into several styles of seating arrangements, included U-shape seating arrangement. Furthermore, the students sometimes use U-shape for discussion.

Also, every class has 38 students on average, so the teacher thinks it's effective to have discussion uses U-shape. Therefore, according to those reasons above, the researcher does research there. This study is aimed to analyze the effectiveness of U-Shape seating arrangement for discussion in speaking class of the first grade students at SLTP Negeri 2 Pematang Raya.

\section{Review of Literatures}

\subsection{Review of Previous Study \\ a. Journal of Englis h Teaching}

There was a journal involved a research about seating arrangement entitled "Classroom Seating Arrangements: Instructional Communication Theory versus Student Preferences". That research summary was written by James C. McCorskey and Rod W. McVetta. Dr. McCorskey is a professor and Chairperson of the Department of speech communication at West Virginia University, and Mr. McVetta is a doctoral candidate specializing in communication in instruction at the same institution. They researched about three common seating arrangements: traditional arrangement, horsehoe arrangement, and modular arrangement. 
The research questions were:

1. Do the students have differential preferences for the three common types of classroom arrangements?

2. Does the type of course to be taken affect student preferences for classroom arrangement?

Subjects were 972 college students who were enrolled in two basic courses in communication and a lecture course with over 300 students per section. The results of their research: The answer of their research questions concerning whether students have differential preferences among the three common types of classroom arrangement is clear. Generally, students in this study indicated a preference for traditional arrangement for required course.

However, the students indicated preferences for horsehoe and modular arrangement for elective course. In brief, type of course has a major influence on arrangement preferences. This differential preference was very clear for the students with low communication apprehension (CA). In general preferences, subjects with low CA favored the horsehoe and modular arrangement, while high $\mathrm{CA}$ favored the traditional arrangement.

\subsection{Effective Teaching and Learning}

"Learning is a change in the individual due to instruction of that individual and his environment, which feels a need and makes him more capable of dealing adequately with his environment". (Moh. Uzer Usman, 1993:4)

In that statement, there is a word 'change' means people who have passed learning process would get changes of behavior whether it is in knowledge, skill or attitude. "People has learnt if they got good moral, for example he can't respect each other well, then after passing learning process he can respect each other". (M. Joko Sulilo, 2006:157).

\subsection{Speaking}

Speaking is an important aspect in language, because speaking is used to communicate among people. By speaking, people can convey information and ideas, and maintain social relationship by communicating with others. As speakers, people used their speech to create an image of themselves to others. By using speed and pausing, and various pitches, volume and intonation, they also create a texture for their talk that supports and enhances what they are saying. The sound of people's speech is meaningful and that is why this is important for assessing speaking. (Sari Luoma, 2003: 10)

Speaking is different with four keys skill in a language learning, because the other three of language skill can be done alone by people but people can't really speak by themselves. Therefore, if people want to be competent in speaking English, they need to be confident to deliver their ideas well. Speaking is a language skill that has to be mastered by students in learning a language because the objective of learning a language is communication (Syakur, 2020). Speaking English well also helps students access up to update information in fields including science, technology and health (Sari, 2019).

\subsection{Discussion}

Discussion is the sight process of two or more individuals that have interaction verbally with certain aim by sharing information, defending the opinion, or solving the problem. According to Hasibuan ((1995:20), discussion is one kind of teaching methods which is used by the teacher to give student chance (groups of students) of making a 
discussion for collecting opinions, making a summary, or making an alternative way to solve the problem.

"Discussion is included of communicative activities which is the most easy to do because it is not limited to certain topics" (Furqonul Azies \& Chaedar Alwasih, 1996:95). All interesting and useful topics can be a theme in discussion activities.

\subsection{Seating Arrangement}

Seating arrangements is an important aspect of classroom management. Teachers have to have to consider both students' physical arrangement and their affective. The way a class should be arranged clearly depends on the purpose of teaching and learning, availability of time, and also implementation of active students' learning style. (Syaiful Bahri Djamarah, 2005: 175).

\subsection{The Effectiveness of U-Shape Arrangement for Discussion}

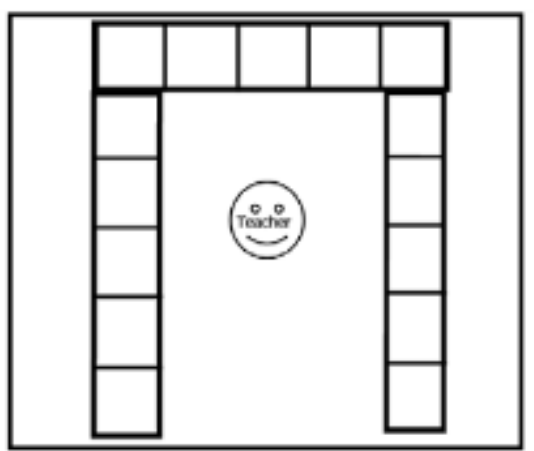

Figure 1. U-shape Seating Arrangement

U-Shape arrangement is a seating arrangement style in which a large number of students sit in U-Shaped arrangements (John W. Santrock, 2006:456). Seating is usually on the outside of the U, but it's possible to seat the students on both inside legs of the U. In this arrangement, teachers can easily see each student and they can see him/her and instructional aides. The philosophies of the teacher using this arrangement could be direct instruction or collaborative.

\section{Research Methods}

\subsection{Research Design}

This research is conducted in term of qualitative research paradigm. This research is purposed to give more detailed explanation of a phenomenon. Therefore, this research is categorized into descriptive clarified research. It focuses on the effectiveness of U-Shape seating arrangement for discussion in speaking class of the first grade students at SLTP Negeri 2 Pematang Raya.

\subsection{Research Setting}

The writer does the research at SLTP Negeri 2 Pematang Raya, more specific at the first grade students. This research is conducted in 7A class only. SLTP Negeri 2 Pematang Raya has competent English teachers, comfortable and wide classrooms for students, also other facilities that support English teaching and learning process. 


\subsection{Subject of the Study}

This study is conducted to the first grade students of SLTP Negeri 2 Pematang Raya.

\subsection{Data of the Study}

Data of this study are collected from the result of observation checklist, questionnaire, and teacher's interview.

\subsection{Data Collection Technique}

\section{a. Observation}

In this research, the data collected by the researcher whereas the researcher didn't include in teaching process. It means the researcher is an observer only and do not take part in teaching and learning process. Observation was conducted during teaching and learning process on the first and second day of the research. The researcher does observation directly to describe the real situation during discussion in speaking class. Then, all of the result of observation is written descriptively.

\section{b. Questionnaire}

List of questions of questionnaire are appropriate with the research problems. And then, the questionnaire was copied as number as students at the first grade students (1A) of SLTP Negeri 2 Pematang Raya. After that, the researcher distributed them to the students. After collecting those questionnaires, the researcher analyzed them by using percentage technique. The sum of students' response of one item question is divided into the number of the students' answer and multiplied by $100 \%$.

\section{c. Interview}

The interview is conducted in order to get more specific information about the study and also to support the data gained from questionnaire and observation. The researcher interviewed the teacher in the last day of the research in SLTP Negeri 2 Pematang Raya.

\subsection{Research Instrument}

The instruments to collect the data can be described below:

\section{a. Observation}

The researcher uses observation to look for information during teaching and learning English process in the class that involves of U-Shape seating arrangement for discussion.

\section{b. Ques tionnaire}

The researcher uses questionnaire to collect information from the respondent (1st grade students of SLTP Negeri 2 Pematang Raya). Generally, by using questionnaire the researcher wants to know the students' responses toward U-shape seating arrangement for discussion.

\section{c. Interview}

The researcher uses teacher's interview to get specific information related with his study. Data that is gained from interview supports the data of observation and questionnaire which has been collected. 


\subsection{Data Analysis}

After getting all the data, the researcher classifies the data into two parts, the qualitative and quantitative data. To analyze the result of checklist observation, the researcher counts the score of checklist observation from the total score gotten in each indicator. Then, the researcher counts the mean score by using rule the total score of each indicator is divided into the total of sub-indicators.

It can be written as follow:

The total score of each indicator

$$
\sum \text { sub-indicators }
$$

To analyze all data from questionnaire, the researcher uses formula: the sum of students' response of one item question will be divided into the number of the students and multiplied by $100 \%$. It can be rewritten as follow:

Sum of students' response of one item question

Total number of students

$$
\text { x } 100 \%
$$

\section{Results and Discussion}

\subsection{Result}

\section{a. The Implementation of U-Shape Seating Arrangement}

The first research question of this study is about the implementation of U-shape seating arrangement. To answer it, the researcher uses observation checklist. There are three indicators being measured in the observation checklist, and each indicator contains several sub indicators. However, the researcher analyzes indicator number one only to answer the first research question. Then, the result of observation checklist is analyzed below:

1. The Result of First Day Observation

First day observation of the research was done on Tuesday, May 31st, 2012.

Table 1. First Day Observation

\begin{tabular}{|c|c|}
\hline Mean Score & First Day Observation \\
\hline 3.25 & $\begin{array}{r}\text { Teacher's and students' role to implement U- } \\
\text { shape seating arrangement }\end{array}$ \\
\hline
\end{tabular}

The result of mean score above is 3.25. It is gotten from the total score of each indicator is divided into the total number of sub-indicators. The total score of first indicator in 1 st meeting is 13 , whereas total number of sub indicators is 4 sub-indicators. Then, to get mean score, 13 is divided into 4 , so the result is 3.25 . It can be written as follow:

$\frac{\text { Total score of each indicator }}{\text { Total number of sub indicators }}=\frac{13}{4}=3.25$


The result of mean score above is 3.25. It means that the teacher's and students' role to implement U-shape seating arrangement is good. On the first day observation, the researcher came in the 1A class with the English teacher at seven o'clock in the morning. The English teacher was Mrs. Siburian. First of all, the teacher opened the class by addressing the students, then allowing the researcher to introduce herself to the students. The introduction took about three minutes. It did not take a long time, because two days before the teacher said to the students that there would be university student who were going to do observation for a research in the class. Then, the teacher said to the students that they would have discussion in U-shape seating arrangement.

Then, the teacher drew a big U-shape on the white board to make clearer the instruction. After that, she gave a clear instruction to the students to arrange their seat into U-shape. It took about fifteen minutes to arrange the students' seat. At first, they faced difficulties to arrange their seat. Some students looked confused how to move their seat, so the class looked noisy and uncontrolled. However, next they were able to arrange their seat into U-shape, because they helped each other. The teacher and the researcher only waited for and monitored the students. They did not help the students, because they wanted to know how long the students arrange their seat into U-shape. The researcher sat in front of the class close to the teacher, because she thought that it was the best angle to observe the students well.

The teacher divided the class into six groups, and each group consisted of four or five students. Then, the teacher asked the students to move and gather with their group.

Generally, according to the result of checklist observation, the researcher concluded that teacher's and student's role to implement U-shape seating arrangement was good. First, the teacher gave instruction very clearly to the students to arrange their seat into Ushape. Second, the teacher drew a big U-shape on the white board to make clearer the instruction. The last, the students were able to arrange their seat. Even though they faced troubles to arrange their seat, but finally they were able to arrange their seat well.

\section{The Result of Second Day Observation}

The second day observation of the research was done on Thursday, June 2nd, 2012.

Table 2. Second Day Observation

\begin{tabular}{|c|c|}
\hline Mean Score & Second Day Observation \\
\hline 3.5 & $\begin{array}{r}\text { Teacher's and students' role to implement U- } \\
\text { shape seating arrangement }\end{array}$ \\
\hline
\end{tabular}

The result of mean score above is 3.5. It is gotten from the total score of each indicator is divided into the total number of sub-indicators. The total score of first indicator in 2 nd meeting is 14 , whereas the total number of sub indicators is 4 sub-indicators. Then, to get mean score, 14 is divided into 4 , so the result is 3.5 . It can be written as follow:

$\frac{\text { Total score of each indicator }}{\text { Total number of sub indicators }}=\frac{13}{4}=3.25$

On second day observation, the researcher and the teacher came in the class at seven o'clock in the morning. When Mrs. Siburian and the researcher came in the class, the students were in busy moving their seat into U-shape seating arrangement, so the class 
seemed a little bit noisy. Therefore, when Mrs. Siburian came in the class, she didn't need to give instruction to the students to arrange their seat into U-shape, because the students had exactly known what they should do. Two days before, Mrs. Siburian asked the students to prepare their seat into U-shape, because they would have discussion again.

As a result, the teacher was able to make use of times to give the students warmer activity before beginning the lesson. Also, the students didn't face many troubles to arrange their seat just like they faced on first day observation. However, on second day observation, the teacher did not take a part in implementing U-shape seating arrangement for discussion. Two days before, Mrs. Siburian asked the students to arrange their seat into U-shape, so the students moved their seat without waiting for the instruction again.

\section{b. The Fffectiveness of U-Shape Seating Arrangement for Discussion}

The second research question of this study is about the effectiveness of U-shape seating arrangement for discussion. To answer it, the researcher uses observation checklist and questionnaire. The researcher analyzes indicator number two and three in observation checklist to answer the second research question. While for questionnaire, the researcher analyzes questions number 15 up to 20 . The results of observation checklist and questionnaire are analyzed below:

1. The Result of First Day Observation

Table 3. First Day Observation

\begin{tabular}{|c|c|}
\hline Mean of Score & First Day Observation \\
\hline 3,3 & Teacher's activity \\
\hline 3,5 & Students' activity (during discussion) \\
\hline 3,2 & Students' activity (after discussion) \\
\hline
\end{tabular}

The mean score is gotten from the total score of each indicator is divided into the total number of sub-indicators. The total score of 2 nd indicator (teacher's activity) is 20 , and there are 6 sub-indicators. Then, 20 is divided into 6 equal 3.33. The total score of $3 \mathrm{rd}$ indicator (students' activity during discussion) is 21 , and there are 6 sub-indicators. Then, 21 is divided into 6 equal 3.5. The total score of 3rd indicator (students' activity after discussion) is 16 , and there are 5 sub-indicators. Then, 16 is divided into 5 equal 3.2. Those calculations can be written as follow:

Mean Score of indicator 2 (teacher's activity)

$\frac{\text { Total score of each indicator }}{\text { Total number of sub indicators }}=\frac{20}{6}=3.33$

Mean Score of indicator 3 (during discussion)

$\frac{\text { Total score of each indicator }}{\text { Total number of sub indicators }}=\frac{21}{6}=3.2$

Mean Score of indicator 3 (after discussion) 
$\frac{\text { Total score of each indicator }}{\text { Total number of sub indicators }}=\frac{16}{5}=3.2$

The procedures of implementing U-shape seating arrangement on 1st meeting have been explained before. Therefore, here the researcher reviews the teacher's activity and students' activity, so the second research question can be answered by analyzing those indicators. After the students implemented U-shape seating arrangement, the teacher began the discussion by dividing the class into six groups, whereas each group consisted of four or five students. After the students gather on group, she asked the students to open their book, page 177 .

However, that problem did not give big obstacle in discussion process. Based on the result of mean score, the students' activity was good. It means they were able to easily discuss in U-shape seating arrangement. During discussion in U-shape seating arrangement, the students were able to deliver their idea freely, focus on the material of discussion, and easily watch the teacher, instructional aides and other students. Therefore, in the end of teaching and learning process, most of them could achieve the purposes of study. Most of them understood the material of the discussion well, got new vocabularies and new information from the discussion text. However, the students did not know how to show their opinion very well, because many students forgot using expression of giving opinion when they wanted to deliver their opinion in the discussion. Also, there were also some students who could not achieve purpose of the study well, because during discussion they prefer to be passive students rather than to be active one. It is probably caused by uninteresting material of discussion, so not all students actively participate in the discussion.

2. The Result of Second Day Observation

Table 4. Second Day Observation Mean of Score Second Day Observation

\begin{tabular}{|c|c|}
\hline Mean of Score & First Day Observation \\
\hline 3,67 & Teacher's activity \\
\hline 3,67 & Students' activity (during discussion) \\
\hline 3,4 & Students' activity (after discussion) \\
\hline
\end{tabular}

The mean score is gotten from the total score of each indicator is divided into the total number of sub-indicators. The total score of 2 nd indicator (teacher's activity) is 22, and there are 6 sub-indicators. Then, 22 is divided into 6 equal 3.67. The total score of 3 rd indicator (students' activity during discussion) is 22 , and there are 6 sub-indicators. Then, 22 is divided into 6 equal 3.67. The total score of 3rd indicator (students' activity after discussion) is 17 , and there are 5 sub-indicators. Then, 17 is divided into 5 equal 3.4. Those calculations can be written as follow:

Mean Score of indicator 2 (teacher's activity)

$\frac{\text { Total score of each indicator }}{\text { Total number of sub indicators }}=\frac{22}{6}=3.67$

Mean Score of indicator 3 (during discussion) 
$\frac{\text { Total score of each indicator }}{\text { Total number of sub indicators }}=\frac{22}{6}=3.67$

Mean Score of indicator 3 (after discussion)

$\frac{\text { Total score of each indicator }}{\text { Total number of sub indicators }}=\frac{17}{5}=3.4$

The procedures of implementing U-shape seating arrangement on 2nd meeting have been explained before. Therefore, in this section, the researcher reviews the teacher's activity and students' activity, so the second question of the research can be answered by analyzing those indicators.

\subsection{Discussion}

Students' learning is effective indicated by each element of teaching and learning works well, the students feel satisfied with the result of study, teaching and learning process is supported by good facilities, material and method are affordable, and the teacher is professional.

As a result, in the end of the lesson, the students can achieve the purposes of study well. Based on the result of observation, questionnaire, and teacher's interview, the researcher concludes that U-shape seating arrangement is effective for discussion.

On the first day and the second day observation, the researcher finds several facts that support that statement. U-shape seating arrangement makes the teacher easier to lead the discussion, because the teacher can easily monitors the students. It is parallel what Ramsden states that "teachers can easily see each student, whereas students can see their teacher and instructional aides in U-shape seating arrangement".

In this case, the teacher has full control over students. Beside, the students can work easily together without making much noise, because they are sitting directly next to each other which make hands on activities and collaborative learning possible.

According to Collins, the openness of this set up gives each student a sense of freedom that encourages wider participants, while the amount of space between students avoids the effect of compression.

In the questionnaire result, $59.26 \%$ of students states that they can much freely participate in discussion when implementing U-shape seating arrangement. The observation checklist also clearly reveals that the students can actively deliver their opinion during discussion in U-shape seating arrangement. Due to the fact that the discussion process goes on well, the students can achieve the purposes of the study in the end of the lesson.

However, U-shape seating arrangement is not appropriate for all teaching and learning purposes. U-shape arrangement is not good for small group works, because the students can't really easily do works together.

It is probably caused by a fact that they can't do many movements in U-shape seating arrangement. In contrast, clusters and centers are strongly effective for collaborative learning activities. In clusters and centers, small member of students work in closely bunched group. However, there are differences between clusters and centers. In 
clusters, all groups get same activities or assignment. In centers, actually they do not work in group. They work individually, but they sit closely with several

students who get same activity. It means each table is given an activity that is different from others. At each table that the students go, they will be actively engaged in the activity. The students are doing their individual work, but they are all helping each other. Due to the fact that the students sit in closely bunched group, in these arrangements, the students can easily see each other and discuss with their group. On the other hand, traditional arrangement reduces social interaction among students, so it is the worst seating arrangement for collaborative learning.

Here, the students can't easily interact with others. Traditional arrangement is very effective for individual work. In U-shape seating arrangement, the students in a group seem a little bit difficult to see each other. It is probably caused by the students in a group who have to stretch their necks when they want to do works together. Based on the result of questionnaire, a half of number of the students state that they get a little bit difficulties to interact with the students in a group. However, the discussion on first day observation and second day observation still went smoothly. Collins states that the students can focus on the discussion when implementing U-shape seating arrangement.

Based on the questionnaire result, $59.26 \%$ of number of the students state that they can focus on the discussion, while $18.52 \%$ of them state that they can strongly focus on the discussion in U-shape seating arrangement. Cluster is also commonly used for discussion, but it is usually used in a small discussion among the students in each group. However, in clusters seating arrangement, the students can't focus on the front of the room, because they may have their back to the teacher.

The students also probably can't focus on the front of the room in center seating arrangement, because they also may have their back to the teacher. On the other hand, in traditional arrangement, most students can focus their attention on front of the room, because all desks are put facing the teacher. However, there are some students who have to sit in the corners and in the back of the room. In these locations in the classroom, students participate and interact less and more behavioral

problems occur.

Therefore, teacher can't make sure that all of students get attention to the lesson Traditional and U-shape seating arrangement is good for direct instruction. In these arrangements, teacher can see all of students, whereas all students can easily see the blackboard, overhead projector, and other instructional aides.

Based on the result of observation, the teacher is easily able to give instructions to the students and the students can clearly listen to the discussion in U-shape seating arrangement. In questionnaire, $77.78 \%$ of students state that they can clearly listen to the discussion. It proves that direct instruction also can be given by teacher in this arrangement. In clusters and centers, teacher may get difficulties to give direct instruction, because students may not be oriented toward them. The class can get loud and out of hand due to the fact that this arrangement is very social. As a result, the students will have difficulties listening to and following directions.

Clusters, centers, and U-shape seating arrangement is not good for individual work, for example for test taking. In U-shape seating arrangement, the students sit next to each other, so they must be easy to cheat each other. In contrast, traditional arrangement is good when numerous tests are given and direct instruction is prevalent so the cheating possibilities can be minimized.

In brief, there is no best seating arrangement which is appropriate for all teaching and learning purposes. Each of them has positive and negative points. Therefore, before 
implementing seating arrangement styles, teachers should make sure that teaching and learning purposes are appropriate to seating arrangement.

\section{Conclusion}

Based on the results and discussion in chapter IV, the researcher takes the conclusions to answer the problems of the study as follow:

1. The teacher uses her strategy to implement U-shape seating arrangement for discussion in speaking class of the first grade students at SLTP Negeri 2 Pematang Raya.

2. U-shape seating arrangement is effective for discussion due to some proofs. First, Ushape seating arrangement helps the teacher leading the discussion well. The teacher can clearly give instruction to the students, easily monitor the students, and easily interact with the students during discussion in U-shape seating arrangement on the first day and second day observation.

3. The students show good responses toward U-shape seating arrangement for discussion. $55.56 \%$ of number of the students state that they like implementing U-shape seating arrangement for discussion, and $22.22 \%$ of number of the students state that they like implementing U-shape seating arrangement for discussion very much. Besides, $51.85 \%$ of the students state that they feel comfortable with U-shape seating arrangement for discussion, and $33.33 \%$ of them state that they feel much comfortable.

\section{References}

Anita Woolfolk, Educational Psychology Tenth Edition, USA: Pearson Education, 2007.

Daniel Muijs and David Reynolds, Effective Teaching: Teori dan Aplikasi, Yogyakarrta: Pustaka Pelajar, 2008.

Furqonul Azies \& Chaedar Alwasih, Pengajaran Bahasa Komunikatif, Jakarta: Rineka Cipta, 1996.

Geoff Petty, A Practical Guide Teaching Today, United Kingdom: Nelson Thornes Ltd, 2004.

Harmer, Jeremy , How to Teach English, England: Longman Person.1998.

James C. McCorskey, James and McVetta Rod W., "Classroom Seating Arrangements: Instructional Communication Theory versus Student Preferences”. 2007.

J.J. Hasibuan, Dip. Ed, Proses Belajar Mengajar, Bandung: Remaja Rosdakarya, 1995.

John W. Santrock, Educational Psycology, United States: Mc Graw Hill, 2006.

Luoma, Sari. Assessing Speaking, United Kingdom:Cambridge University Press. 2003.

Moh. Uzer Usman, Upaya Optimalisasi Kegiatan Belajar Mengajar, Bandung: Remaja

M. Joko Sulilo, Gaya Belajar Menjadikan Makin Pintar, Yogyakarta: Pinus Book Publisher, 2006.

Penny, Ur, A Course In Language Teaching, Cambridge: Cambridge university press, 1996.

Sari, P. A. S., and Sembiring, R.K. (2019). Improving Students' English Speaking Skill Through the Implementation of Talking Stick Method to the Fifth Grade Students of State Primary School 028226 Binjai. Budapest International Research and Critics in Linguistics and Education (BirLE) Journal Vol 2 (4): 507-513.

Syaiful Bahri Djamarah, Guru dan Anak Didik Dalam Interaksi Edukatif, Jakarta: Rineka Cipta, 2005. 
Syakur, A. (2020). Improving English Language Speaking Skills Using "Absyak" On-Line Learning Model for Second Semester in Higher Education. Budapest International Research and Critics in Linguistics and Education (BirLE) Journal Vol 3 (2): 684694.

Wallwork , Adrian, Discussion A-Z, United Kingdom: Cambridge University Press. 